direct representation of the medical profession on this board. This is also true of the navy, for its Medical Department is represented on the General Board. Oddly enough, the anachronism still exists that in the General Staff of the United States Army the Medical Department is regarded as an outsider. The safeguarding of the health and fighting vigor of an army, the salvage of its wounded, the saving of man power through protection from disease are still regarded as forreign to staff organization. The medical and sanitary formations are still regarded as non-combatants, although those serving with the troops often go forward and mingle with them in the combats, that the morale of the men may be better sustained. Duty demands it, and they have shown themselves willing, in this war; to be unarmed combatants, not non-combatants. The ratio of the medical offeers killed and dying of wounds has been exceeded only by that of the infantry and artillery, which branches necessarily bear the brunt of the battles. The pro rata death rate of the medical officers has exceeded that of aviators and of engineers.

This subject is a matter for congressional action, but the profession of this country, while the experiences of this war are still vivid in its mind, must turn to the Congress, must make an intelligent exposition of these facts, and must bring about, by legal enactment, an adequate representation of the Medical Department on the General Staff of the army.

I desire to draw but one more deduction from the medical lessons of this great war, and that in reality is the climax toward which everything points. That is, if this nation, through its present medical knowledge, has within its grasp the power to control communicable, and hence preventable, diseases, there must be established a nation-wide controlling organization for this purpose a $\mathrm{Na}$ tional Department of Health. Over 33 : per cent. of our younger men were disqualified from the draft for physical defects. There is need of wider supervision of our growing boys and girls to build up a more robust nation, and it is especially urgent in rural districts. If we are to have some form of uni- versal military service, the very necessity of its universality demands some general supervision of the health of the youth of the nation, through protection against the transmissible diseases, and direction over the giving of health to the people as we now give education. This war has taught that there remains economic value in the maimed and wounded, and it is our duty to develop this value to its fullest extent. The maiming and injury of our workers, in the every-day work of industry, far exceeds each year the battle casualties of this war, and there is an economic necessity and duty to be performed in the salvage and reconstruction of the industrially injured.

Malaria still prevents the use of large areas of our southern 'states, and saps the energy of a large portion of the population. Typhoid fever still rests as a blot on the rural hygiene of this country. The control of epidemics between states is already in the hands of the Public Health Service, and within states, if state authorities request aid. Quarantine from outsidé infection is also under federal control. There are many other federal activities partially supervising health and disease through the various departments of the federal government. But it all lacks the efficient power of central correlation, and there remain many public health activities that should be undertaken by central action, from some of the problems of infant mortality to the problems of the increase of degenerative diseases. of late middle life. It is the duty of the American Medical Association, and of each member of each state association, to urge on Congress the establishment of a National Department of Health.

\section{WALTER GOULD DAVIS}

THE meteorological service of the Argentine Republic will be the enduring monument of Walter Gould Davis, whose death on April 30, at his old homestead in Danville, Vt., removed one of the world's best-known and most highly respected meteorologists.

As a young man Mr. Davis went to Argentina to serve as assistant to Dr. Benjamin 
Apthorp Gould, who founded the Astronomical Observatory at Cordoba, and, in 1872, established the Argentine Meteorological Service, which was installed in the Astronomical Observatory, the two organizations being independent of one another, although under the same director. Dr. Gould continued in charge of this service until towards the end of 1884 , when he left Argentina, and in 1885, Mr. Davis succeeded him as director, continuing in that position until his retirement in May, 1915, after thirty years of active work. Under Mr. Davis's able leadership, the Argentine Meteorological Service attained a position in the very front rank of government meteorological organizations. When he resigned his post, to secure well-deserved rest and to seek to regain his health in his own country, the Argentine service extended over an area of nearly 3,000 miles in a north- and south-line, its southernmost station being in the South Orkney Islands, in latitude $60^{\circ} 43^{\prime}$ south. Over 2,000 stations were then cooperating in the work of taking meteorological and magnetic observations. The morning and evening observations from nearly 200 stations were being used in the construction of the daily weather map, in addition to the daily rainfall records from about 1,350 rainfall stations.

The development of meteorological work under Mr. Davis was rapid and many-sided. In 1885 , the year in which he became director, the Meteorological Office (Oficina Meteorologica Argentina) was made a separate organization, and its headquarters were moved from the Astronomical Observatory to a larger and better building, especially built for the purpose, the grounds immediately adjoining. In 1901 the central office was moved to Buenos Aires, where the telegraphic and other facilities for the preparation of a daily weather map, publication of which was begun on February 21,1902 , were much greater than at Cordoba. A hydrometric section was established in 1902; a magnetic section and a forecasting service in 1904; a rainfall service in 1912, and a system of weekly, or longer forecasts in 1915. The section of climatic statistics has continued to have its headquarters at Cordoba, where it collects and compiles climatological data, maintains a first-class observatory, and is carrying on researches in agricultural meteorology.

Mr. Davis was a tremendously keen, active and progressive director. He was not only an unusually efficient executive officer, but he was also a man of wide learning and of a great variety of interests. Both as director, and as a man, he had the respect and loyal devotion of all his associates and employees. He was always well abreast of the times, and often was a pioneer in keeping ahead of the times. Not content with covering the mainland of his great district with meteorological stations, he extended his service into the Antarctic province to the south. An illustration of his desire to have the organization under his control contribute in every possible way to the adrancement of meteorological knowledge was his acquirement, in 1904, of the meteorological and magnetic station at Laurie Island, in the South Orkneys, which had originally been established by the Scottish Antarctic Experition. Since 1904, this remote southern station has been operated, without a break in its records, as a part of the Argentine Meteorological Service. The personnel of this lonely outpost is relieved only once each year, when supplies are sent for the coming twelve months. The men are then completely isolated, without (at last accounts) any mail or cable communication, until the relief vessel returns the following year. Under these conditions of extreme loneliness and hardship, the observers at Laurie Island have maintained their observations for fifteen years. This is a remarkable record of scientific work of the greatest importance in the study of world meteorology. In his Laurie Island station Mr. Davis always took great pride, and well he might do so.

Fully alive to all the needs of his service, Mr. Davis called to help him in his scientific work the best meteorologists whom he could find. From this country, he secured Professor F. H. Bigelow, formerly of the Weather $\mathrm{Bu}$ reau, who has had charge of the magnetic work in Argentina since September, 1915; Mr. H. H. Clayton, formerly of Blue Hill Observatory, and since 1913 chief of the De- 
partment of Forecasts in Buenos Aires; Mr. L. G. Schultz, chief of the magnetic section until 1915 and others. Mr. George O. Wiggin, the present director of the Argentine Meteorological Office, is also a native of the United. States.

The high quality of Mr. Davis's work was fully appreciated by his meteorological colleagues everywhere. His reputation as a meteorologist and as the successful administrative head of a large and remarkably efficient organization won for him a position on the International Meteorological Committee, the highest international authority on meteorology. This was a well-deserved recognition of the importance of his contributions to meteorology, and of his sound judgment on scientific matters.

The many publications of the Argentine Meteorological Service which were issued under Mr. Davis's direction constitute an inspiring record of splendid work, well planned, thoroughly organized, and ably carried out. For comparatively few countries are there available such excellent meteorological and climatological publications, some of them in English, as the Argentine Meteorological Service has sent out.

By the death of Walter Gould Davis the world has lost one of its most eminent meteorologists, and those of his colleagues who had the privilege of knowing him have lost a warm-hearted, sympathetic and helpful friend.

ROBERT DEC. WARD

HARVARD UNIVERSITY, May 31, 1919

\section{SCIENTIFIC EVENTS}

\section{THE VOLCANIC ERUPTION IN JAVA}

Offricral advices received by the State Department report that the recent eruption of the Klot (or Kalut) volcano in Java cost 40,000 native lives, destroyed 20,000 acres of crops, principally rice, by its flow of hot mud, and did millions of dollars' damage by the falling ashes in regions outside the devastated districts. The National Geographic Society has issued from its Washington headquarters the following bulletin:
Volcano-made in the first place, and constantly being remade by them, Java has more volcanoes than any area of its size in the world. Estimates of the active and extinct eraters range from 100 to 150. Everywhere in Java, in the huge crater lakes, in fissures that now are river beds, even in ancient temples, half-finished when interrupted by some fiery convulsion, are evidences of cataclysmic forces-such turbulent forces as now are in continuous hysteria in the Valley of the Ten Thousand Smokes in Alaska and break their crusted surface cage intermittently in Java.

The "treacherous Klot," as the natives call it, all but wiped out the town of Britar, but even its devastation, as reported to the State Department, was mild compared to the violent upheaval of Krakatoa in 1883. Then mother nature turned anarchist and planted a Gargantuan infernal machine on the doorstep of Java. Krakatoa is a little island in the Sunda Strait, between Sumatra and Java. Australians, as far from the explosions as New York is from El Paso, heard the terrific detonation, more than half the island was blotted out, parts of it were flung aloft four times as high as the world's highest mountain, and to touch bottom below the water's surface, where most of the island has been, henceforth required a plumb line twice as long as the height of the Washington Monument. Skyscraper waves flooded adjacent islands and rolled half way around the earth. Every human ear drum heard, though it may not have registered, the air waves as they vibrated three or four times around the earth.

Krakatoa levied a smaller toll in human life than Klot because of its isolation, and many of the 35,000 deaths from Krakatoa's eruption were at far distant points by drowning.

An eruption anywhere on the island means disaster. For Java, about equal in area to New York state, supports a population greater than the combined populations of the empire state and the four other most populous states in the Union-Pennsylvania, Illinois, Ohio and Texas.

\section{EXPEDITION FROM THE CALIFORNIA MUSEUM OF VERTEBRATE ZOOLOGY TO ALASKA}

THE museum of vertebrate zoology of the University of California has again undertaken field work in Alaska, and a party to work in that region left the Museum on May 14, to be gone until October 1 . The route for the present season is to lie in southeastern Alaska in the vicinity of Wrangell. It will 